\title{
Colostrum and milk quality of sows fed different diets during mid-pregnancy
}

\author{
J. Więcek', A. Rekiel, J. Bartosik, R. Głogowski and B. Kuczyńska \\ Warsaw University of Life Sciences - SGGW, Faculty of Animal Sciences, Department of Animal Breeding and Production \\ 02-786 Warsaw, Poland
}

KEY WORDS: sows, nutrition, lactation, pregnancy, energy levels, fatty acids

Received: 27 September 2017

Revised: $\quad 4$ June 2018

Accepted: $\quad 23$ August 2018

${ }^{1}$ Corresponding author:

e-mail: justyna_wiecek@sggw.pl

\begin{abstract}
The aim of the study was to assess the quality of colostrum and milk with reproductive performance in sows offered different feed allowances from day 41 to 70 of gestation. In the study 20 F1 sows (Polish Landrace x Polish Large White), 10 animals per group: Control and Experimental, were used. During mid-pregnancy period, sows received $2.3 \mathrm{~kg}$ (Control) and $3.0 \mathrm{~kg}$ (Experimental) of feed daily. Samples of colostrum (farrowing day) and milk (day 21 of lactation) were collected and its chemical composition, fatty acid profile, and somatic cell count (SCC) were determined. Piglets were counted and weighed at parturition and at day 21 of life. Colostrum collected from sows from Experimental group contained more fat $(P<0.05)$ than that from Control group. Tendency to higher protein content in milk was observed in the Experimental group. SCC in the colostrum and milk of sows from Experimental group was higher than that in Control group $(P<0.01$ and $P<0.05$, respectively). The higher proportion of PUFA n6 in milk was noted in milk from Experimental group $(P<0.01)$. There were no significant differences between groups regarding reproductive performance; however body weight of piglets at 21 day of age and piglet daily body weight gain in Experimental group tended to be higher than that in Control. Therefore, it seems appropriate to increase the feed allowances for sows to $3 \mathrm{~kg}$ feed/day from days 41 to 70 of pregnancy in order to gain more beneficial chemical composition and fatty acid profile of colostrum and milk. Moreover, the tendency to improve piglet growth performance can be observed.
\end{abstract}

\section{Introduction}

Numerous scientific reports documented that the quality of sow milk plays a major role in the piglets rearing (Szyndler-Nędza et al., 2013; Kim et al., 2018). Milk fat content, however, may be significant at the rearing only in the first weeks of piglet life (Ren et al., 2017). It was previously demonstrated that sow colostrum, milk quality and yield depend on many factors, both genetic and environmental, including breed, sow condition, type of feeding, number of nursed piglets, and lactation stage, as well as teat number and structure (Beyga and Rekiel, 2009; Rekiel et al., 2011, 2015; Koska and Eckert, 2016). Jin et al. (2016) reported no significant differences in the chemical composition of colostrum and milk in gilts fed diets with increased energy levels.

It is known that fat and fatty acid concentrations in the milk of sows can be manipulated by dietary interventions during gestation and lactation. The additional influence on the milk fat content and quality have the sow's body fat reserves (Amdi et al., 2013). Bee (2000) showed that in sows during gestation conjugated linoleic acid (CLA) supplementation 
markedly altered colostrum and milk fatty acid composition. Furthermore, Eastwood et al. (2014) described fatty acid content in colostrum and both, early and late lactation milk, as similar to that of respective gestation dietary profiles.

The findings of Beyer et al. (2007), King'ori (2012) and Szyndler-Nędza et al. (2013) pointed the effect of feeding sows in early and late pregnancy on the quantity and quality (chemical composition) of the colostrum and milk produced, which are essential for piglet rearing. Gestating gilts and sows should be fed such a dietary energy level as to maintain an optimal body condition and reproductive performance, but should not be overfed or underfed (Wang et al., 2016).

Recent findings suggest that it is unfavourable to feed sows the same diet during transition and lactation and that either phase feeding or a two component strategy is more optimal (Feyera and Theil, 2017).

The importance of feeding level in sows, during different phases of gestation was previously demonstrated, indicating that specific nutritional modifications can affect primary: secondary muscle fibres ratio in progeny (Bee, 2004; Cerisuelo et al., 2009).

Renetal.(2018) reported no differences in numbers of total born piglets from sows offered different levels of feed intake $(0.5,1.0,1.5$ and 2.0 of maintenance energy) during four short (7 days) periods of gestation (in total 28 days). However, both piglet weight at birth and at weaning were maximized at 1.5 level.

Interestingly, extra feed allowance from day 40 to 85 of gestation did not lead to differences in litter size or piglet body weight at farrowing and on day 18 of lactation both in gilts and multiparous sows (Cerisuelo et al., 2009).

In an interesting review on 'bump feeding' in gilts and sows during late gestation, Gonçalves et al. (2016) underlined that unproportioned increase in the intake of all nutrients leads to inconclusive results in reproductive performance.

The objective of the study was to evaluate the quality of colostrum and milk from sows offered increased dietary allowance during mid-gestation.

\section{Material and methods}

The experiment was approved by the Local Ethics Committee for Animal Experimentation (decision No. 5/2010, Poland).

\section{Animals and feeding}

Twenty F1 sows (Polish Landrace $\times$ Polish Large White) inseminated with the semen of Duroc boars (second reproductive cycle) were randomly assigned to Control and Experimental group, 10 animals per group. Until day 28 of gestation all sows were kept in single crates. From day 29 to 103 sows were moved to group pen for pregnant sows, consuming individual feed ration, dispensed by an automated feeding station (Compident 6, Schauer Agrotronic $\mathrm{GmbH}$, Prambachkirchen, Germany). At day 104 all animals were placed in individual farrowing crates and stayed there till the end of lactation. Throughout the whole gestation and lactation sows were kept on solid floor with shallow straw bedding. Samples of colostrum and milk were taken from all sows in both groups.

Table 1. Feeding scheme of sows during pregnancy

\begin{tabular}{llcccc}
\hline \multirow{2}{*}{ Daily allowance } & \multirow{2}{*}{ Group } & \multicolumn{5}{c}{ Gestation period, days } \\
\cline { 2 - 6 } & & $1-40$ & $41-70$ & $71-90$ & $91-110$ \\
\hline Feed, kg & control & 2.3 & 2.3 & 2.3 & 3.2 \\
& experimental & 2.3 & 3.0 & 2.3 & 3.2 \\
\multirow{2}{*}{ ME, MJ } & control & 28.8 & 28.8 & 28.8 & 40.0 \\
& experimental & 28.8 & 37.5 & 28.8 & 40.0 \\
\multirow{2}{*}{ Crude protein, g control } & 285 & 285 & 285 & 397 \\
& experimental & 285 & 372 & 285 & 397 \\
\hline
\end{tabular}

$\mathrm{ME}$ - metabolizable energy

During early gestation sows in both groups received the same daily amounts of feed until day 40 $(2.3 \mathrm{~kg}, 29 \mathrm{MJ}$ of metabolizable energy (ME)/d) (Nutritional Recommendations for Pigs, 1993) (Table 1). From day 41 to 70 of gestation, the groups were offered different daily feed allowances, according to the following scheme: $2.3 \mathrm{~kg} /$ animal/day in Control and increased to $3.0 \mathrm{~kg} / \mathrm{animal} /$ day in Experimental group. Estimated daily amounts of ME offered in Control and Experimental groups were 29 and $38 \mathrm{MJ}$, respectively. The diets used in the experiment were two complete balanced mixtures: LP - for pregnant and LK - for lactating sows (12.5 MJ ME/kg) (de heus Polska, Łęczyca, Poland) (Table 2). All sows had ad libitum access to water.

In the periparturient period, different amounts of feed were administered: each animal received $2 \mathrm{~kg}$ (25 MJ ME) (LP + wheat bran) from days 111 to 114 of pregnancy; $0.5-1 \mathrm{~kg}$ of bran on the farrowing day; and subsequently daily ration each day increased by an average of $1 \mathrm{~kg}$ of LK (12.5 MJ $\mathrm{ME)}$ for 3-4 days following farrowing.

During lactation, all 20 sows received daily $2 \mathrm{~kg}$ of the complete mixture per animal for maintenance, as well as additional $0.5 \mathrm{~kg}$ of that mixture for every nursed piglet.

All piglets had access to prestarter mixture from day 10 . The individual weighing was performed at days 1 and 21, and at weaning (day 35). The litter control was performed in both groups. 
Table 2. Ingredients and basic composition of the sow diets

\begin{tabular}{lll}
\hline \multirow{2}{*}{ Indices } & Mixture & \\
\cline { 2 - 3 } & pregnant sow (LP) & nursing sow (LK) \\
\hline Feed materials, \% & & \\
maize, ground & 35 & 40 \\
wheat, ground & 30 & 20 \\
wheat, bran & 25 & 25 \\
concentrate HGC & 10 & 15 \\
SOW & & \\
Basic composition, \% & & \\
dry matter & 88.8 & 90.0 \\
crude ash & 4.2 & 5.4 \\
crude protein & 12.4 & 16.5 \\
crude fat & 1.9 & 1.8 \\
crude fibre & 5.2 & 2.8 \\
Calculated & & \\
ME, MJ & 12.5 & 12.5 \\
lysine, g & 5.6 & 7.9 \\
methionine, g & 3.6 & 5.0 \\
threonine, g & 3.8 & 5.1 \\
\hline
\end{tabular}

${ }^{1}$ nutritional value of concentrate HGC SOW (de heus Polska, Łęczyca, Poland) per $1 \mathrm{~kg}$ : g: crude protein 380, lysine 31.6, methionine 5.8, threonine 15.5, Ca 60, Na 16, P 9; IU: vitamin A 80,000, vitamin $D_{3}$ 13,300; mg: vitamin E 400, Cu 100, Zn 667, Mn 267, Fe 834, Se 1.30, I 20; FTU: phytase 1809; ME - metabolizable energy

\section{Samples and analyses}

The ingredients and the chemical composition of the mixtures for sows are presented in Table 2 . Basic analyses of the mixtures were performed according to commonly accepted procedures (AOAC International, 2005).

Samples of colostrum (farrowing day) and milk (day 21 of lactation) were collected from the sows (50 ml/animal) into vessels containing milk preservative (Mlekostat CC, Zekar, Brwinów, Poland). Prior to the collection, the sows were intramuscularly injected with oxytocin $(1 \mathrm{ml} / 100 \mathrm{~kg}$ body weight). The somatic cell count (SCC) in colostrum and milk was determined with a Bentley Somacount 150 (Bentley Polska, Warsaw, Poland). The collected samples were analysed for total chemical composition and the content of solids, protein, fat and lactose with use of infrared spectrophotometer Milkoscan FT 120 (Foss Electric, Warsaw, Poland).

Fatty acids were extracted from the colostrum and milk according to the Rose-Gottlieb method (AOAC International, 2005), in which protein was dissolved in $25 \%$ ammonia solution and fat extracted with organic solvents. Ethyl esters were separated by gas chromatography. The gas chromatograph (Hewlett Packard 6890 Series GC, Perlan Technologies, Warsaw, Poland) was equipped with flame ionization detector (FID) and capillary column HP 23 (Perlan Technologies, Warsaw, Poland) (length: $60 \mathrm{~m}$, diameter: $0.25 \mathrm{~mm}$, film: $0.15 \mu \mathrm{m}$ ). The temperature profile of the analysis was: initial temperature $130^{\circ} \mathrm{C}$ for $1 \mathrm{~min}, 5.5^{\circ} \mathrm{C} / \mathrm{min}$ up to $175^{\circ} \mathrm{C}$ for $10 \mathrm{~min}, 2.8^{\circ} \mathrm{C} /$ min up to $230^{\circ} \mathrm{C}$ for $15 \mathrm{~min}$. Total analysis time was $54 \mathrm{~min}$.

The fatty acid profile was determined, and the $\%$ values were given for:

- saturated fatty acids (SFA): C14:0, C16:0, C18:0,

- monounsaturated fatty acids (MUFA): C16:1, C18:1 n9, C20:1 n9,

- polyunsaturated fatty acids n3 (PUFA n3): C18:3 n3, C20:4 n3, C20:5 n3, C22:5 n3, C22:6 n3,

- polyunsaturated fatty acids n6 (PUFA n6): C18:2 n6, C18:3 n6.

\section{Statistical analysis}

The results were statistically analysed using a SPSS Statistics 24 (IBM Polska, Warsaw, Poland). SCC was transformed using logarithmic function. Normality of the variables was tested using ShapiroWilk test. Since the distributions were not normal, the groups were compared with the use of non-parametric U-Mann Whitney test. This test compares distributions of the variables based on sums of ranks of the observations. The tables present means and standard deviations. The differences were considered significant at $P<0.05$ and the tendency was stated when $0.05<P<0.1$.

\section{Results}

In sows from Experimental group fat content $(P=0.03)$ in colostrum was higher than that in Control (Table 3). The SCC logarithm differed significantly between groups $(P=0.003)$ and was higher in the Experimental group.

Table 3. Parameters of the basic composition of colostrum and milk

\begin{tabular}{|c|c|c|c|c|c|}
\hline \multirow{3}{*}{ Indices } & \multicolumn{4}{|l|}{ Group } & \multirow{3}{*}{$P$-value } \\
\hline & \multicolumn{2}{|c|}{ control } & \multicolumn{2}{|c|}{ experimental } & \\
\hline & mean & SD & mean & SD & \\
\hline \multicolumn{6}{|l|}{ Colostrum } \\
\hline solids, \% & 24.87 & 3.91 & 26.49 & 2.78 & 0.368 \\
\hline protein, $\%$ & 13.76 & 1.51 & 13.82 & 0.83 & 0.691 \\
\hline fat, $\%$ & 5.66 & 3.09 & 6.35 & 0.63 & 0.030 \\
\hline lactose, \% & 3.10 & 0.49 & 4.45 & 2.59 & 0.202 \\
\hline LN SCC & 5.05 & 0.93 & 5.90 & 0.70 & 0.003 \\
\hline \multicolumn{6}{|l|}{ Milk } \\
\hline solids, \% & 18.66 & 1.19 & 19.42 & 1.51 & 0.174 \\
\hline protein, \% & 4.61 & 0.81 & 5.22 & 0.91 & 0.054 \\
\hline fat, $\%$ & 7.10 & 0.65 & 7.66 & 1.21 & 0.137 \\
\hline lactose, $\%$ & 6.11 & 0.83 & 5.42 & 0.83 & 0.007 \\
\hline LN SCC & 4.94 & 0.51 & 5.65 & 0.63 & 0.030 \\
\hline
\end{tabular}

SD - standard deviation; LN SCC - natural logarithm of somatic cell count 
The analyses confirmed that the milk (content of solids and fat) of sows from Experimental group did not differ from the Control group (Table 3). Higher lactose content was determined in the milk of sows from Control group $(P=0.007)$, whereas a tendency to higher protein content was noted in the Experimental group $(P=0.054)$. Moreover, there were found differences in the natural logarithm of SCC in milk and colostrum $(P=0.03)$ - the values were higher in Experimental group.

No significant differences were observed in the fatty acid profile of colostrum. However in the Experimental group $\mathrm{C} 14: 0$ and $\mathrm{C} 16: 1$ were higher $(P=0.027$ and $P=0.021$, respectively; Table 4$)$. There were also observable tendencies in lower proportion of $\mathrm{C} 18: 0, \mathrm{C} 18: 1 \mathrm{n} 9$ and $\mathrm{C} 18: 2 \mathrm{n} 6$ in the Experimental group $(P=0.066, P=0.93$ and $P=0.083$, respectively).

The SFA and MUFA proportions in milk were comparable between the groups except C18:0 (decreased in Experimental group, $P=0.021$ ) (Table 5). The proportion of PUFA n6 was higher in Experimental group than in Control one $(P=0.005)$ mainly due to the higher proportion of C18:2 n6 found in the milk of Experimental sows $(P=0.005)$. The proportion of PUFA n3 in milk was almost similar between the groups. The proportion of total PUFA was lower in the milk of Control sows in comparison to Experimental $(P=0.004)$.

Table 4. Fatty acid profile in the colostrum, $\%$

\begin{tabular}{|c|c|c|c|c|c|}
\hline \multirow{3}{*}{$\begin{array}{l}\text { Fatty } \\
\text { acids }\end{array}$} & \multicolumn{4}{|l|}{ Group } & \multirow{3}{*}{$P$-value } \\
\hline & \multicolumn{2}{|l|}{ control } & \multicolumn{2}{|c|}{ experimental } & \\
\hline & mean & SD & mean & SD & \\
\hline $\mathrm{C} 14: 0$ & 1.49 & 0.31 & 1.95 & 0.35 & 0.027 \\
\hline C16:0 & 24.92 & 1.51 & 25.62 & 3.03 & 0.985 \\
\hline C18:0 & 7.82 & 1.00 & 6.79 & 0.80 & 0.066 \\
\hline C16:1 & 3.48 & 0.70 & 5.43 & 2.36 & 0.021 \\
\hline C18:1 n9 & 41.40 & 2.43 & 39.04 & 3.38 & 0.093 \\
\hline C20:1 n9 & 0.32 & 0.07 & 0.31 & 0.10 & 0.792 \\
\hline C18:2 n6 & 12.02 & 2.73 & 10.19 & 1.46 & 0.083 \\
\hline C18:3 n6 & 0.26 & 0.08 & 0.27 & 0.05 & 0.672 \\
\hline C18:3 n3 & 0.63 & 0.15 & 0.61 & 0.11 & 0.752 \\
\hline C20:4 n3 & 0.68 & 0.20 & 0.68 & 0.10 & 0.916 \\
\hline C20:5 n3 & 0.04 & 0.01 & 0.04 & 0.02 & 0.636 \\
\hline $\mathrm{C} 22: 5$ n3 & 0.25 & 0.08 & 0.20 & 0.08 & 0.172 \\
\hline $\mathrm{C} 22: 6$ n3 & 0.02 & 0.01 & 0.03 & 0.01 & 0.214 \\
\hline SFA & 34.25 & 2.25 & 34.37 & 3.01 & 0.875 \\
\hline MUFA & 45.20 & 2.22 & 44.78 & 4.05 & 0.401 \\
\hline PUFA n6 & 12.28 & 2.75 & 10.46 & 1.45 & 0.115 \\
\hline PUFA n3 & 1.63 & 0.31 & 1.56 & 0.16 & 0.916 \\
\hline PUFA & 13.91 & 2.87 & 12.02 & 1.43 & 0.172 \\
\hline
\end{tabular}

SFA - saturated fatty acids, MUFA - monounsaturated fatty acids PUFA - polyunsaturated fatty acids
Table 5. Fatty acid profile in the milk, \%

\begin{tabular}{|c|c|c|c|c|c|}
\hline \multirow{3}{*}{ Fatty acids } & \multicolumn{4}{|l|}{ Group } & \multirow{3}{*}{$P$-value } \\
\hline & \multicolumn{2}{|l|}{ control } & \multicolumn{2}{|c|}{ experimental } & \\
\hline & mean & SD & mean & SD & \\
\hline $\mathrm{C} 14: 0$ & 2.61 & 1.07 & 2.39 & 0.68 & 0.773 \\
\hline C16:0 & 25.77 & 1.93 & 27.01 & 3.11 & 0.441 \\
\hline C18:0 & 6.89 & 0.88 & 5.87 & 1.51 & 0.021 \\
\hline C16:1 & 3.93 & 0.43 & 6.24 & 3.33 & 0.386 \\
\hline C18:1 n9 & 38.14 & 2.11 & 37.51 & 4.74 & 0.923 \\
\hline C20:1 n9 & 0.36 & 0.06 & 0.33 & 0.07 & 0.308 \\
\hline C18:2 n6 & 7.41 & 1.16 & 10.23 & 1.92 & 0.005 \\
\hline C18:3 n6 & 0.20 & 0.04 & 0.19 & 0.06 & 0.595 \\
\hline C18:3 n3 & 0.62 & 0.18 & 0.57 & 0.13 & 0.531 \\
\hline C20:4 n3 & 0.66 & 0.12 & 0.73 & 0.16 & 0.335 \\
\hline C20:5 n3 & 0.05 & 0.01 & 0.04 & 0.02 & 0.441 \\
\hline C22:5 n3 & 0.20 & 0.07 & 0.20 & 0.07 & 0.801 \\
\hline C22:6 n3 & 0.02 & 0.01 & 0.02 & 0.01 & 0.383 \\
\hline SFA & 35.27 & 2.60 & 35.26 & 3.48 & 0.773 \\
\hline MUFA & 42.43 & 2.07 & 44.09 & 4.05 & 0.386 \\
\hline PUFA n6 & 7.61 & 1.17 & 10.42 & 1.93 & 0.005 \\
\hline PUFA n3 & 1.55 & 0.23 & 1.56 & 0.25 & 0.847 \\
\hline PUFA & 9.16 & 1.07 & 11.98 & 1.91 & 0.004 \\
\hline
\end{tabular}

SFA, MUFA, PUFA - see Table 4

Number of piglets at days 1 and 21 of age and body weight of piglets at day 1 of age did not differ between groups (Table 6). Body weight of piglets at day 21 of age $(P=0.081)$ and piglet daily body weight gain $(P=0.072)$ in Experimental group tended to be higher as compared to Control group.

Table 6. Piglet number and weight

\begin{tabular}{lrrrrrr}
\hline \multirow{3}{*}{ Indices } & \multicolumn{3}{l}{ Group } & & \\
\cline { 2 - 5 } & \multicolumn{1}{c}{ control } & \multicolumn{3}{c}{ experimental } & P-value \\
\cline { 2 - 5 } & mean & SD & \multicolumn{1}{c}{ mean } & SD & \\
\hline Piglets born alive, $\mathrm{n}$ & 10.92 & 0.84 & 11.08 & 1.02 & 0.742 \\
Piglets reared until day 21, $\mathrm{n}$ & 10.30 & 0.78 & 10.53 & 0.95 & 0.654 \\
BW of piglet at day 1, kg & 1.55 & 0.03 & 1.50 & 0.04 & 0.334 \\
BW of piglet at day 21, kg & 5.77 & 0.25 & 6.24 & 0.32 & 0.081 \\
Piglet daily BW gain, g & 201.95 & 42.34 & 226.71 & 51.09 & 0.072 \\
Piglet mortality in days & 5.56 & 3.24 & 4.96 & 3.01 & 0.375 \\
1-21 of life, \% & & & & & \\
\hline BW - body weight & & & & &
\end{tabular}

\section{Discussion}

Feeding female animals is reflected in their condition including body fat and protein reserves and body weight (Rekiel et al., 2016). The latter contributes to the amount of milk produced, especially in the early lactation period (Beyer et al., 2007; Yang et al., 2008; Beyga and Rekiel, 2009; King'ori, 2012). Feeding pregnant and nursing sows mixtures 
containing higher amounts of lipids and/or proteins helps improve the quality of milk, in particular fat and protein contents (Tilton et al., 1999; Cordero et al., 2011; Szyndler-Nędza et al., 2013). The consequence of such feeding is not only a higher neonatal weight but a higher growth rate of piglets in the first weeks of life, which is determined by birth weight and colostrum and milk quality (Lauridsen and Jensen, 2007; Yang et al., 2008; Cordero et al., 2011).

Also in the present study the increased feed allowance during mid-gestation influenced colostrum and milk content with tendencies observed in piglet performance. Our results are in agreement with previously published data (Wang et al., 2016), reporting that increasing the feeding level of sows to $3 \mathrm{~kg}$ feed/day from days 41 to 70 of pregnancy resulted in higher fat content in the colostrum. This effect can be considered beneficial, in regard to previously reported positive association of the sow colostrum fat level with body weight, growth rate and lower mortality in piglets (Skrzypczak et al., 2015). Modification of the pregnant sow diets in our study had also a positive effect on the quality of milk. Although fat content was not increased like in the colostrum, tendency in higher protein content was stated. This effect was probably due to the beneficial changes in the energy and protein reserves of mothers receiving higher energy diets. On the other hand the lactose content was decreased in the Experimental group in comparison to Control. Revell et al. (1998), Rekiel et al. (2015), Koska and Eckert (2016) reported that milk lactose content is strictly related to the fatness of sows, but their results were inconsistent. In fatter sows, Revell et al. (1998) found lower milk lactose levels than those in thinner sows. On the other hand, the findings of Rekiel et al. (2015) and Koska and Eckert (2016) indicated that females with greater fat reserves produce milk with a higher lactose content. In the present study the lactose content was higher in the milk of sows from the Control group; however the fatness of the sows was not measured.

The SCC values obtained in the current experiment can be considered beneficial (Beyga and Rekiel, 2009) although the SCC in the colostrum and milk of sows from the Experimental group were higher than in Control. Indeed, Szyndler-Nędza et al. (2013) observed no relationship between SCC and rearing piglet performance.

Besides chemical composition, the examined diet modification of pregnant sows influenced fatty acid profiles of colostrum and milk. In our study, sows in mid-pregnancy fed higher energy diet produced colostrum with higher content of $\mathrm{C} 14: 0$ and $\mathrm{C} 16: 1$ but no difference in total content of SFA, MUFA and PUFA was stated. On the other hand, in the milk a higher content of linoleic acid (C18:2 n6) was observed in sows fed diet with increased feed allowance, and so the total PUFA n6 content was stated to be higher. The fatty acids profile of colostrum and milk is crucial as high PUFA content has a positive effect on piglet immunity, survival and rearing performance (Bassaganya-Riera et al., 2001). The effect of sow nutrition on the fatty acid profile of colostrum and milk has been already stated by Tilton et al. (1999), Barowicz et al. (2002) or Cordero et al. (2011). However attention should be given to the dynamic changes in the fatty acid profile during lactation, especially to the content of the essential fatty acids (EFA): linoleic acid (C18:2 n6) and alphalinolenic acid (C18:3 n3), from which fatty acids with longer carbon chains are formed in animal tissues such as arachidonic acid (C20:4 n6), eicosapentaneoic acid (C22:5 n3) and docosahexaenoic acids (C24:6 n3), crucial for the development of the body immunity (Averette et al., 1999). Feeding sows with fat-enriched diets, Tilton et al. (1999) observed an increase in the level of MUFA (in particular C18:1) and PUFA (C18:2, C18:3 and C20:4). After feeding late-pregnant sows with linoleic acid, Barowicz et al. (2002) found their colostrum and milk to have lower content of unsaturated fatty acids and an increased level of MUFA.

Body weight of piglets at 21 day of age and piglet daily body weight gain in the Experimental group tended to be higher than that in Control. Inconsistent results, however, were recently reported by Ren et al. (2017). Increased feeding of sows in a three short periods of gestation led to lower piglet weight and average weight gain at weaning. This might indicate that milking capacity was not affected by sow feeding level in gestation.

Comparing different standards of sow feeding, regarding the ME requirements, it was stated that results of the present study correspond well with the Nutrient Requirements and Nutritional Values of Feeds for Swine (2015).

\section{Conclusions}

It can be stated that increasing the feeding level of sows to $3 \mathrm{~kg}$ feed/day from 41 to 70 days of pregnancy could be favourable due to the more beneficial chemical composition and fatty acid profile of colostrum and milk. Moreover, the tendency to improve piglet growth performance can be observed. 


\section{References}

Amdi C., Giblin L., Hennessy A.A., Ryan T., Stanton C., Stickland N.C., Lawlor P.G., 2013. Feed allowance and maternal backfat levels during gestation influence maternal cortisol levels, milk fat composition and offspring growth. J. Nutr. Sci. 2, e1, https:// doi.org/10.1017/jns.2012.20

AOAC International, 2005. Official Methods of Analysis of AOAC International. $18^{\text {th }}$ Edition. Gaithersburg, MD (USA)

Averette L.A., Odle J., Monaco M.H., Donovan S.M., 1999. Dietary fat during pregnancy and lactation increases milk fat and insulinlike growth factor I concentration and improves neonatal growth rates in swine. J. Nutr. 129, 2123-2129, https://doi. org/10.1093/jn/129.12.2123

Barowicz T., Migdał W., Pieszka M., Živikovic B., 2002. Chemical composition of colostrum and milk of sows fed conjugated linoleic acid (CLA) during last period of pregnancy. Biotech. Anim. Husb. 18, 27-32

Bassaganya-Riera J., Hontecillas-Magarzo R., Bregendahl K., Wannemuehler M.J., Zimmerman D.R., 2001. Effects of dietary conjugated linoleic acid in nursery pigs of dirty and clean environments on growth, empty body composition, and immune competence. J. Anim. Sci. 79, 714-721, https://doi. org/10.2527/2001.793714x

Bee G., 2000. Dietary conjugated linoleic acids alter adipose tissue and milk lipids of pregnant and lactating sows. J. Nutr., 130, 2292-2298, https://doi.org/10.1093/jn/130.9.2292

Bee G., 2004. Effect of early gestation feeding, birth weight, and gender of progeny on muscle fiber characteristics of pigs at slaughter. J. Anim. Sci. 82, 826-836, https://doi. org/10.2527/2004.823826x

Beyer M., Jentsch W., Kuhla S., Wittenburg H., Kreienbring F., Scholze H., Rudolph P.E., Metges C.C., 2007. Effects of dietary energy intake during gestation and lactation on milk yield and composition of first, second and fourth parity sows. Arch. Anim. Nutr. 61, 452-468, https://doi.org/10.1080/17450390701563433

Beyga K., Rekiel A., 2009. Effect of the backfat thickness of sows in late pregnancy on the composition of colostrum and milk. Arch. Anim. Breed. 52, 593-602, https://doi.org/10.5194/aab52-593-2009

Cerisuelo A., Baucells M.D., Gasa J., Coma J., Carrión D., Chapinal N., Sala R., 2009. Increased sow nutrition during midgestation affects muscle fiber development and meat quality, with no consequences on growth performance. J. Anim. Sci. 87, 729-739, https://doi.org/10.2527/jas.2007-0677

Cordero G., Isabel B., Morales J., Menoyo D., Piñeiro C., Daza A., Lopez-Bote C.J., 2011. Conjugated linoleic acid (CLA) during last week of gestation and lactation alters colostrum and milk fat composition and performance of reproductive sows. Anim. Feed Sci. Technol. 168, 232-240, https://doi.org/10.1016/j.anifeedsci.2011.04.085

Eastwood L., Leterme P., Beaulieu A.D., 2014. Changing the omega-6 to omega-3 fatty acid ratio in sow diets alters serum, colostrum, and milk fatty acid profiles, but has minimal impact on reproductive performance. J. Anim. Sci. 92, 5567-5582, https:// doi.org/10.2527/jas.2014-7836

Feyera T., Theil P.K., 2017. Energy and lysine requirements and balances of sows during transition and lactation: A factorial approach. Livest. Sci. 201, 50-57, https://doi.org/10.1016/j. livsci.2017.05.001

Gonçalves M.A.D., Dritz S.S., Tokach M.D., Piva J.H., DeRouchey J.M., Woodworth J.C., Goodband R.D., 2016. Fact sheet - Impact of increased feed intake during late gestation on reproductive performance of gilts and sows. J. Swine Health Prod. 24 , 264-266
Jin S.S., Jung S.W., Jang J.C., Chung W.L., Jeong J.H., Kim Y.Y., 2016. Effects of dietary energy levels on the physiological parameters and reproductive performance of gestating gilts. Asian-Australas. J. Anim. Sci. 29, 1004-1012, https://doi. org/10.5713/ajas.16.0269

Kim J.S., Hosseindoust A., Ju I.K., Yang X., Lee S.H., Noh H.S., Lee J.H., Chae B.J., 2018. Effects of dietary energy levels and $\beta$-mannanase supplementation in a high manna-based diet during lactation on reproductive performance, apparent total tract digestibility and milk composition in multiparous sows. Ital. J. Anim. Sci. 17, 128-134, https://doi.org/10.1080/1828 051X.2017.1345663

King'ori A.M., 2012. Sow lactation: colostrum and milk yield - a review. J. Anim. Sci. Adv. 2, 525-533

Koska M., Eckert R., 2016. Effect of fatness of sows on colostrum and milk chemical composition and their reproductive performance (in Polish). Rocz. Nauk Zootech. 43, 147-162

Lauridsen C., Jensen S.K., 2007. Lipid composition of lactational diets influences the fatty acid profile of the progeny before and after suckling. Animal 1, 952-962, https://doi.org/10.1017/ S175173110700033x

Nutrient Requirements and Nutritional Value of Feeds for Swine (in Polish). $2^{\text {nd }}$ Edition. Grela E.R., Skomiał J. (Editors), 2015. The Kielanowski Institute of Animal Physiology and Nutrition, Polish Academy of Sciences, Jabłonna (Poland)

Nutritional Recommendations for Pigs (in Polish), 1993. The Kielanowski Institute of Animal Physiology and Nutrition, Polish Academy of Sciences. Jabłonna (Poland)

Rekiel A., Bartosik J., Wieccek J., 2016. Evolution of nutrition and its effect on the condition and productivity of sows (in Polish). Zesz. Probl. Post. Nauk Roln. 584, 81-93

Rekiel A., Więcek J., Beyga K., 2011. Analysis of the relationship between fatness of late pregnant and lactating sows and selected lipid parameters of blood, colostrum and milk. Ann. Anim. Sci. 11, 487-495, https://doi.org/10.2478/v10220-011-0001-3

Rekiel A., Więcek J., Kuczyńska B., Bartosik J., Warda A., Furman K., 2015. Effect of the backfat thickness at point P2 during insemination on selected parameters of colostrum and milk of the sows. Ann. Warsaw Univ. Life Sci. SGGW. Anim. Sci. 54, 153-160

Ren P., Yang X.J., Kim J.S., Menon D., Baidoo S.K., 2017. Effect of different feeding levels during three short periods of gestation on sow and litter performance over two reproductive cycles. Anim. Reprod. Sci. 177, 42-55, https://doi.org/10.1016/j.anireprosci.2016.12.005

Ren P., Yang X.J., Railton R., Jendza J., Anil L., Baidoo S.K., 2018. Effects of different levels of feed intake during four short periods of gestation and housing systems on sows and litter performance. Anim. Reprod. Sci. 188, 21-34, https://doi. org/10.1016/j.anireprosci.2017.11.001

Revell D.K., Williams I.H., Mullan B.P., Ranford J.L., Smits R.J., 1998. Body composition at farrowing and nutrition during lactation affect the performance of primiparous sows: II. Milk composition, milk yield, and pig growth. J. Anim. Sci. 76, 1738-1743, https://doi.org/10.2527/1998.7671738x

Skrzypczak E., Waśkiewicz A., Beszterda M., Goliński P., Szulc K., Buczyński J.T., Babicz M., 2015. Impact of fat and selected profiles of fatty acids contained in the colostrum and milk of sows of native breeds on piglet rearing. Anim. Sci. J. 86, 83-91, https://doi.org/10.1111/asj.12241

Szyndler-Nędza M., Różycki M., Eckert R., Mucha A., Koska M., Szulc T., 2013. Relationships between chemical composition of colostrum and milk and rearing performance of piglets during a 21-day lactation. Ann. Anim. Sci. 13, 771-781, https://doi.org/10.2478/aoas-2013-0052 
Tilton S.L., Miller P.S., Lewis A.J., Reese D.E., Ermer P.M., 1999. Addition of fat to diets of lactating sows: I. Effect on milk production and composition and carcass composition of the litter at weaning. J. Anim. Sci. 77, 2491-2500, https://doi. org/10.2527/1999.7792491x

Wang J., Yang M., Cao M. et al., 2016. Moderately increased energy intake during gestation improves body condition of primiparous sows, piglet performance, and milk fat and protein output. Livest. Sci. 194, 23-30, https://doi.org/10.1016/j.livsci.2016.09.012
Yang Y., Heo S., Jin Z., Yun J., Shinde P., Choi J., Yang B., Chae B., 2008. Effects of dietary energy and lysine intake during late gestation and lactation on blood metabolites, hormones, milk composition and reproductive performance in multiparous sows. Arch. Anim. Nutr. 62, 10-21, https://doi. org/10.1080/17450390701780227 